II.

\title{
NOTE ON THE CONTENTS OF THE
}

\section{TA'RIKH-I-JAHAN-GUSHA :}

OR HISTORY OF THE WORLD-CONQUEROR, CHANGIZ KHAN, BY 'ATA MALIK JUWAYNI,

with an appreciation and comparison of some of the manuscripts of this work, especially those belonging to the Bibliotheque

Nationale at Paris.

BY EDWARD G. BROWNE, M.A., M.B., M.R.A.S.

No event since the time of the Prophet Muhammad has, probably, so profoundly affected the history of Western Asia as the disastrous wave of Mongol Invasion which, beginning with the first conquests of Changíz Khán at the beginning of the thirteenth century of our era, culminated in the sack of Baghdad and the extinction of the Caliphate by his grandson Húlágú Khán in A.D. 1258.

D'Ohsson, in his great Histoire des Mongols (1834), enumerates the following five Arabic and Persian works as the most important Muhammadan sources for the history of this period :-

1. The well-known Ta'rikhu'l-Kamil of Ibnu'l-Athir, who died in A.H. 630 (A.D. 1232-3), under A.H. 617 and the following years of the chronicle.

2. The Sirat, or Biography, of that valiant antagonist of the Mongols, Jalálu'd-Dín Mankubirtí, the last of the Khwárazmsháhs, composed by his faithful secretary Shihábu'd-Dín Muhammad b. A ḥmad of Nasá in Khurásán. This work, inspired by Ibnu'l-Athír's narrative, comprises 108 chapters, was written in A.H. 639 (A.D. 1241-2), and is characterized by d'Ohsson as "une narration simple et naturelle."

3. The Ta'rikh-i-Jahán-gushá of 'Atáa Malik Juwayní, which forms the subject of the present notice. This history 
was composed in A.H. 658 (A.D. 1260), and is carried down to the death of Ruknu'd-Dín Khursháh, last Grand-Master of the Assassins of Alamút, in A.H. 655 (A.D. 1257), while a few MSS. contain an additional Appendix on the sack of Baghdad, which took place in the following year. The author, who was secretary to Húlágú Khán himself, died in A.H. 681 (A.D. 1282-3).

4. The Kitábu Tajziyati'l-Amṣár va Tazjiyati'l-A'ṣár of 'Abdu'lláh b. Faḍlu'lláh, who (since he was the panegyrist of the Mongol Court) is generally called Wassáfu'l-Hadrat, whence his history is commonly known as the I'a'rikh-iWassäf. It is professedly a continuation of the Jahán-gushá last mentioned (with an abstract of which it concludes), and covers the years A.H. 655-728 (A.D. 1257-1327). Undertaken for Gházán Khán, it was only completed in the time of his successor U'ljáytú, to whom the author, introduced by Rashídu'd-Dín Fadlu'lláh (author of the history to be next mentioned), presented it. The Preface was written in A.H. 699 (A.D. 1299-1300). It is much admired in the East for (what in our eyes is a blemish) its florid and laboured style, over-charged with every species of rhetorical ornament.

5. The Jámi' 'u't-Tawáritih, or great universal history, of Rashídu'd-Dín Fadlu'lláh, the accomplished and unfortunate Minister who was put to death on Sept. 13, A.D. 1318 (A.н. 718). It comprises three volumes, of which the first treats of the general history and ethnology of the Mongols, and, in greater detail, of their history from the time of Changíz Khán till the time of U'ljáytú. This volume was concluded in A.H. 702 (A.D. 1302-3). The second volume deals with the general history of the pre-Mongol period, while the third treats of Geography. The history was brought down by the author to the death of Gházán Khán, while a supplement, composed by Mas'úd b. 'Abdu'lláh in A.Ir. 837 (A.D. 1433-4), carries it down to A.H. 736 (A.D. 1335-6).

Of these five sources, the first two, which are both in Arabic, have been published in extenso, while of the last threes which are all in Persian, portions only (and in the case of the Jahán-gusha only a small portion, in vol. ii of 
Schefer's Chrestomathie persane, pp. 105-169) have been published.

The Jahán-gushá is, then, the most neglected, though by no means the least interesting, of these five important histories; nor is it interesting only by reason of its well-informed and original account of the Mongol Invasion. This, and the Rise and Development of the Mongol power down to the destruction of the Khwárazmsháhs and of the Assassins of Alamút, form the subject of the first volume; while the second and third volumes deal respectively with the history of the two Dynasties last mentioned. The history of the Assassins in particular is discussed with singular fulness and authority, for the author accompanied Húlágú Khán (in his capacity of secretary) on the expedition against their chief strongholds, and was able to examine and note the contents of many rare books in their well-stocked libraries, which were immediately afterwards committed to the flames. Thus it happens that this work contains many particulars concerning the history and doctrines of this interesting sect which are not to be found elsewhere, as well as much matter throwing light on the social and literary history of the period.

The public libraries of Europe contain altogether at least some fourteen manuscripts of this important work, of which I have examined eight more or less fully, viz., the British Museum MS. (Or. 155), the India Office MS. (No. $1914=$ No. 170 in Ethe's Catalogue), and six of the Paris MSS., some of which (in particular a very fine one, dated A.H. 689) are remarkably good. These I shall refer to in the remainder of this article as B.M., I.O., and $\mathrm{P}^{1}-\mathrm{P}^{6}$. For an edition of the text, which I have long contemplated for my Persian Historical Text Series, $\mathrm{P}^{2}$ (Suppl. persan, 205), the ancient MS. above mentioned, would form the proper basis, while B.M. and I.O. are both so incorrect, incomplete, and defaced by dislocations and lacunce, that they might well be ignored, and $I$ only mention them in what follows because they are most accessible to scholars in this country, and because I have myself been compelled to work chiefly at them, using the former in a transeript begun for me by a Turk named 'A'rif 
Bey and concluded by Mawlawí Muhammad Barakatu'lláh, and the latter in the original, which the authorities of the India Office Library, with their usual liberality, placed at my disposal.

I now proceed to an enumeration (which makes no pretence to completeness) of the principal European MSS., adding to those of Paris a brief description, which I deem unnecessary in the case of B.M. and I.O., since descriptions of these will be found in the respective catalogues of the institutions to which they belong.

\section{Paris.}

1. Ancien Fonds persan $69\left(=\mathrm{P}^{1}\right)$. - The MIS. used by d'Ohsson, and, before him, by Quatremère in compiling his notice of the author in vol. i of Mines de l'Orient, pp. 220-234 (Vienna, 1809). He correctly describes it as "un petit in-folio, contenant 189 feuillets (each of 25 lines), et qu'on a achevé de copier le deuxième jour du mois de Moharrem, A.H. 938 (= August 16, A.D. 1531). L'écriture en est mauvaise, et présente un assez grand nombre de fautes de copiste." I may add that this MS. is complete, was transcribed by one named Malu'a' $i$, and contains many marginal notes and collations. It is written in nasta'lí which I should describe as fairly good.

2. Supplément persan $205\left(=\mathrm{P}^{2}\right)$. - A beautiful old MS. dated A.H. 689 (A.D. 1290), comprising ff. 176 of 27 lines. It is a large volume (measuring, if $I$ recollect aright, about $10 \times 8$ inches), and is carefully written in a fine, large, archaic naskhi hand, which is, however, not always easy to read.

3. Supplément persan $206\left(=\mathrm{P}^{3}\right)$. - This MS., dated A.H. 841 (A.D. 1437-8), contains ff. 188, is written in a good naskhi hand, with rubrications, and is embellished with six miniatures. I did not compare its contents throughout with the other MSS., but it is incomplete at the end, and seems to lack the whole, or at least the greater part, of vol. i. There is also a dislocation or lacuna between ff. 41 and 42 . 
The following MSS. belonged to the late M. Charles Schefer, whose wonderful collection of Oriental manuscripts passed entire to the Bibliothèque Nationale.

4. Supplément persan $1375\left(=\mathbf{P}^{4}=\right.$ Pers. 68 of the Schefer Collection).-A fine old complete copy (ascribed by the cataloguer of the Schefer MSS. to the fifteenth century of our era), written in a clear and excellent naskhi hand, and comprising ff. 234. There is, however, between ff. 215 and 216 , an extensive lacuna, corresponding with ff. $155 a$, 1. 12-165a, 1. 24, of $\mathrm{P}^{2}$.

5. Supplement per'san $1556^{1}\left(=\mathrm{P}^{5}=\right.$ Pers. 240 of the Schefer Collection). -A moderately good MS. (ascribed to the fourteenth century of our era) containing ff. 264 (220 written). The writing is rather scratchy and illegible, and the first leaf is supplied in a modern Turkish hand.

6. Supplément persan $1563\left(=\mathrm{P}^{6}=\right.$ Pers. 24 of the Schefer Collection).-A quite modern MS., dated A.H. 1259 (A.D. 1843-4), comprising ff. 199 of 17 ll., the text written in a good, clear $t a^{\prime} l i q$, the verses cited in large, clear naskhi and in red or blue ink. This ends early in vol. iii with the Proclamation announcing the destruction of the Assassins' stronghold of Alamút, omitting the whole account of the Isma'íli sect which should follow this. On f. 168a (the end of vol. ii, here wrongly called the end of vol. i) is a colophon stating that the MS. was copied from an original dated A.H. 659 (A.D. 1261).

In point of excellence I should place these six MSS. in the following order :- $\mathrm{P}^{2}, \mathrm{P}^{4}, \mathrm{P}^{1}, \mathrm{P}^{6}, \mathrm{P}^{5}, \mathrm{P}^{3}$.

\section{LoNDON.}

7. Or. 155 of the British Museum (= B.M.). - This is defective in several places, especially at the beginning of vol. i, where some nine or ten chapters are wanting, and there are also several dislocations, while the text is far from correct. It is quite modern (А.H. $1277=$ A.D. 1860-1), but professes to have been copied from an original dated A.H. 658 (= A.D. 1260). 
8. No. 1914 ( $=170$ of Ethe's Catalogue) of the India Office.-In this also five or six chapters are wanting at the beginning, three (including the conquest of Bukhárá and Samarqand and the revolt of Tárábí) a little further on, and the end of vol. ii and beginning of vol. iii. There are also several dislocations, the proper order of the existing portions being ff. 1-17 (lacuna), 93-180, 18-93, 180-236 (the end). It ends with Nașíru'd-Dín Túsís Appendix (referred to on p. 28 supra), was transcribed in A.H. 1076 (= A.D. 1665-6), and is written in a slovenly $t a^{\prime} l q q$, with rubrications and some marginal notes and references.

\section{OXFORD.}

9. Fraser 154 ( $=$ No. 146 of Ethe's Catalogue) of the Bodleian, not dated, but described by Ethé as "a very old and good copy."

10. Ouseley Add. 44 (= No. 145 of Ethé's Catalogue) of the Bodleian, also not dated.

\section{MANCHESTER.}

11. No. 814 of Lord Crawford's Collection, which, formerly so generously placed at the disposal of scholars, has now passed into the hands of Mrs. Rylands, where it has hitherto proved inaccessible. It is said to date from about A.D. 1700 .

\section{Gotha.}

12. No. 33 Persian (=No. 28 of Aumer's Catalogue), dated A.H. 799 (= A.D. 1396-7), and described as written in a cursive hand.

\section{LEYDEN.}

13. Cod. 1185 Warner.-A modern copy made by a European, and partly collated by Warner, A.D. 1662. 


\section{VienNa.}

14. N.F. 217 (= 956 of Flügel's Catalogue). - This, containing only the first half of the work, is said to have been copied from a MS. in the Library of Sultán Báyezíd at Constantinople, in A.H. 1249 (= A.D. 1833-4).

\section{Constantinople.}

In the Constantinople Catalogues I have found mention of four more copies, viz., 'Amúja Husayn Páshá, No. 359; As‘ad Efendi, No. 2106; Hamídiyya Turbési (Lálá Isma'íl Efendi's bequest), No. 336 ; and Sultán Muhammad Fátih, No. 4316.

I shall now give, in the form of a concordance, the collation of the six Paris MSS., B.M., and I.O., indicating alike the headings of the chapters into which the book is divided, and the place in each MS. where each chapter begins.

\section{Vol. I : HISTORY OF THE MONGOLS.}

The work opens, as usual, with a Doxology, beginning :-

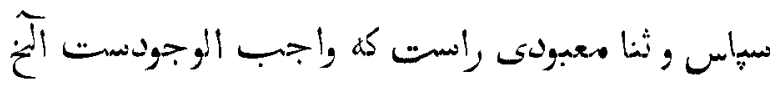

This Doxology is followed by a short introductory section, headed Fass, and beginning :-

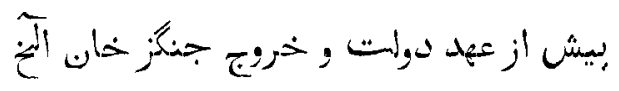

After this follow the chapters into which the book is divided (here numbered for more convenient reference, but not so numbered in any of the MSS.), in all eighty-six, or thereabouts, whereof Nos. 1-40 constitute the first volume, Nos. 41-71 the second, and Nos. 71-86 the third. The titles of each section, with my ordinal numbers prefixed, are given to the right of the page, and the collation of the eight MSS. (so far as I had time to make it during my visit to Paris, for it is not complete) on the left. 
34 THE CONTENTS OF THE TA'RIKH-I-JAHAN-GUSHA.

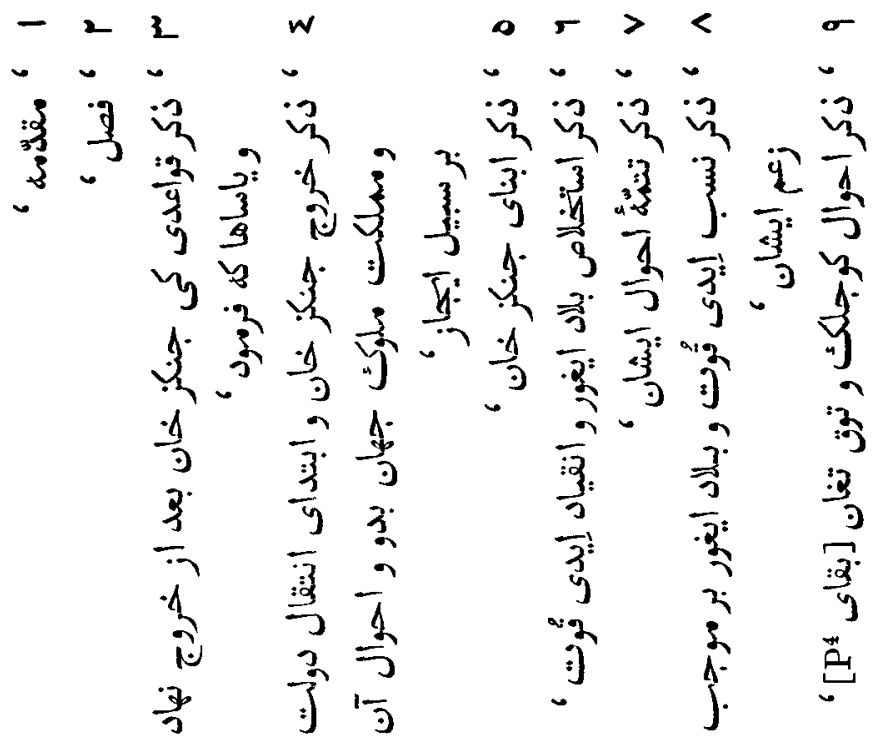

$\stackrel{\dot{0}}{-i}$

$\infty$

$\dot{\text { ค. }}$

$\stackrel{\oplus}{\circ}$

$\infty$

$\underset{\pi}{\infty} \stackrel{8}{\square}$

$\underset{-1}{\infty}$

คै.

$\begin{array}{lll}8 & 0 & 8\end{array}$

$\ddot{\vec{A}}$

$\infty \quad \frac{1}{0}$

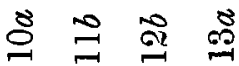

20

$\ddot{n}_{1}$
A.
6
2
$\infty \quad 0$ 요
$\underset{10}{\infty}$
$\overrightarrow{B_{1}}$
ลำ
$\stackrel{0}{2}$ 
THE CONTENTS OF THE TA'RIKH-I-JAHAN-GUSHA. 35

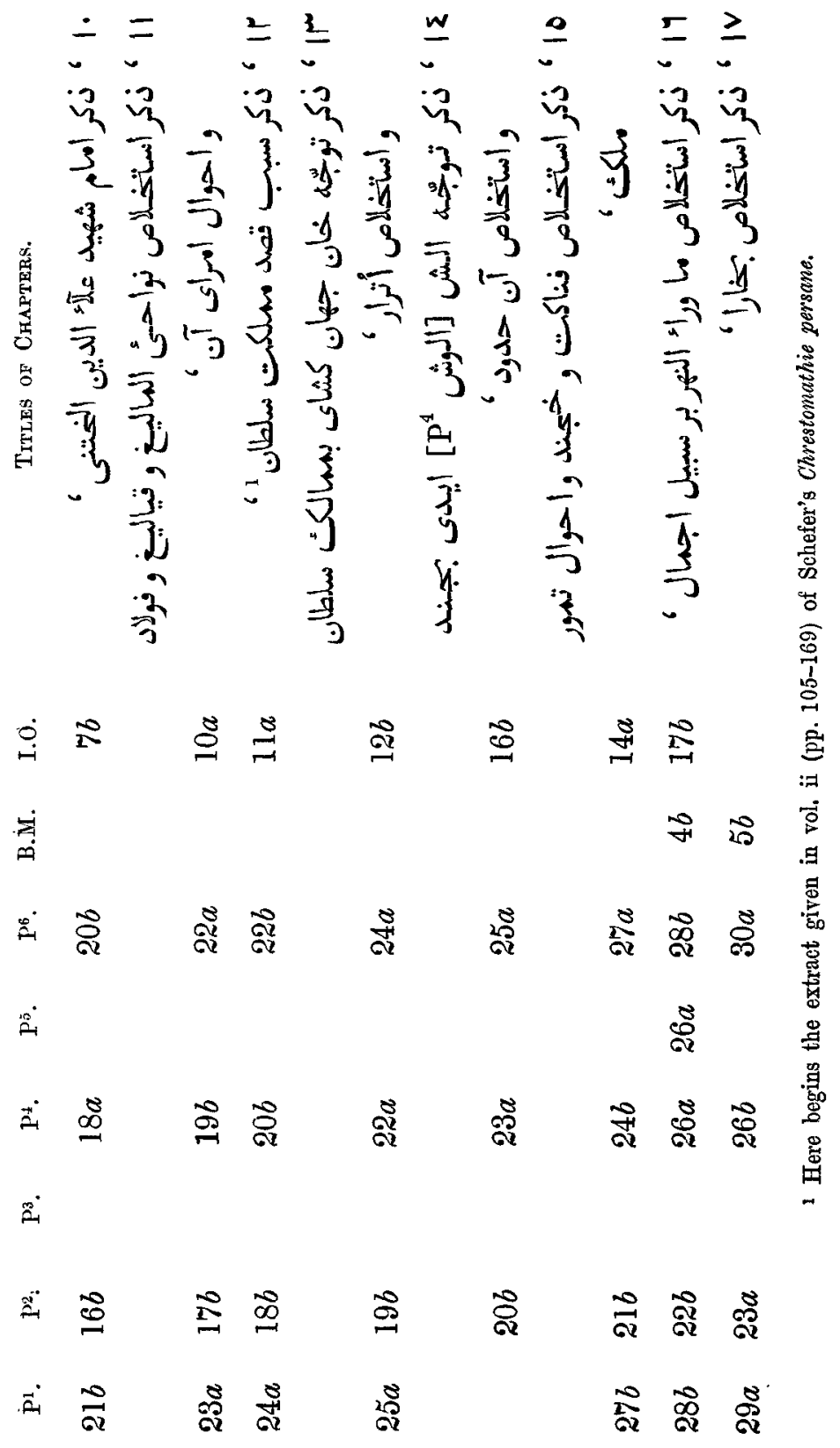




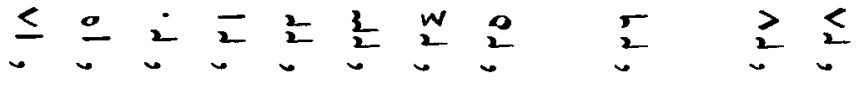

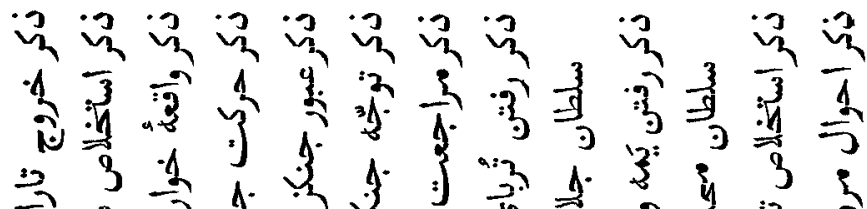

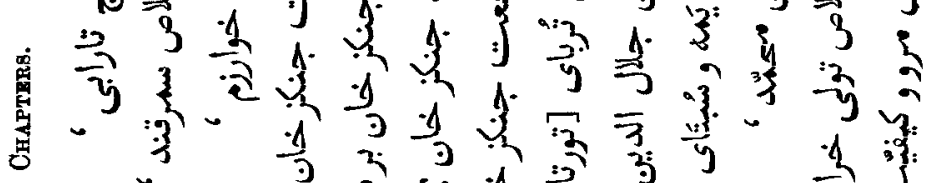

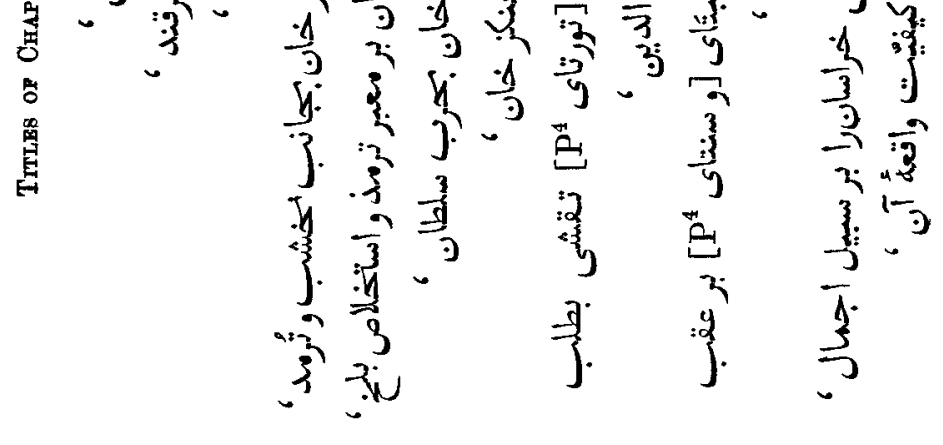

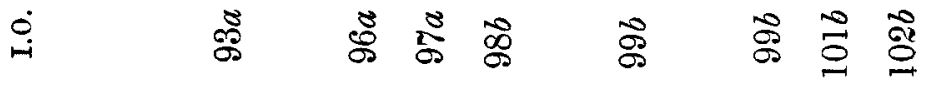

$$
\begin{aligned}
& \text { 래 } \\
& \text { ๕. } \\
& \stackrel{\circ}{\circ}
\end{aligned}
$$

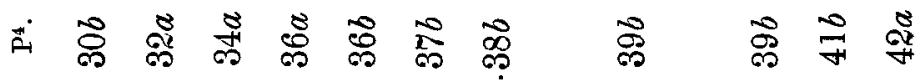

$$
\begin{aligned}
& \text { คै }
\end{aligned}
$$

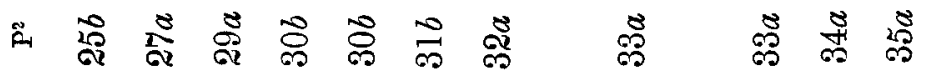

$$
\begin{aligned}
& \text { تี }
\end{aligned}
$$


THE CONTENTS OF THE TA'RIKH-I-JAHAN-GUSHA. 37

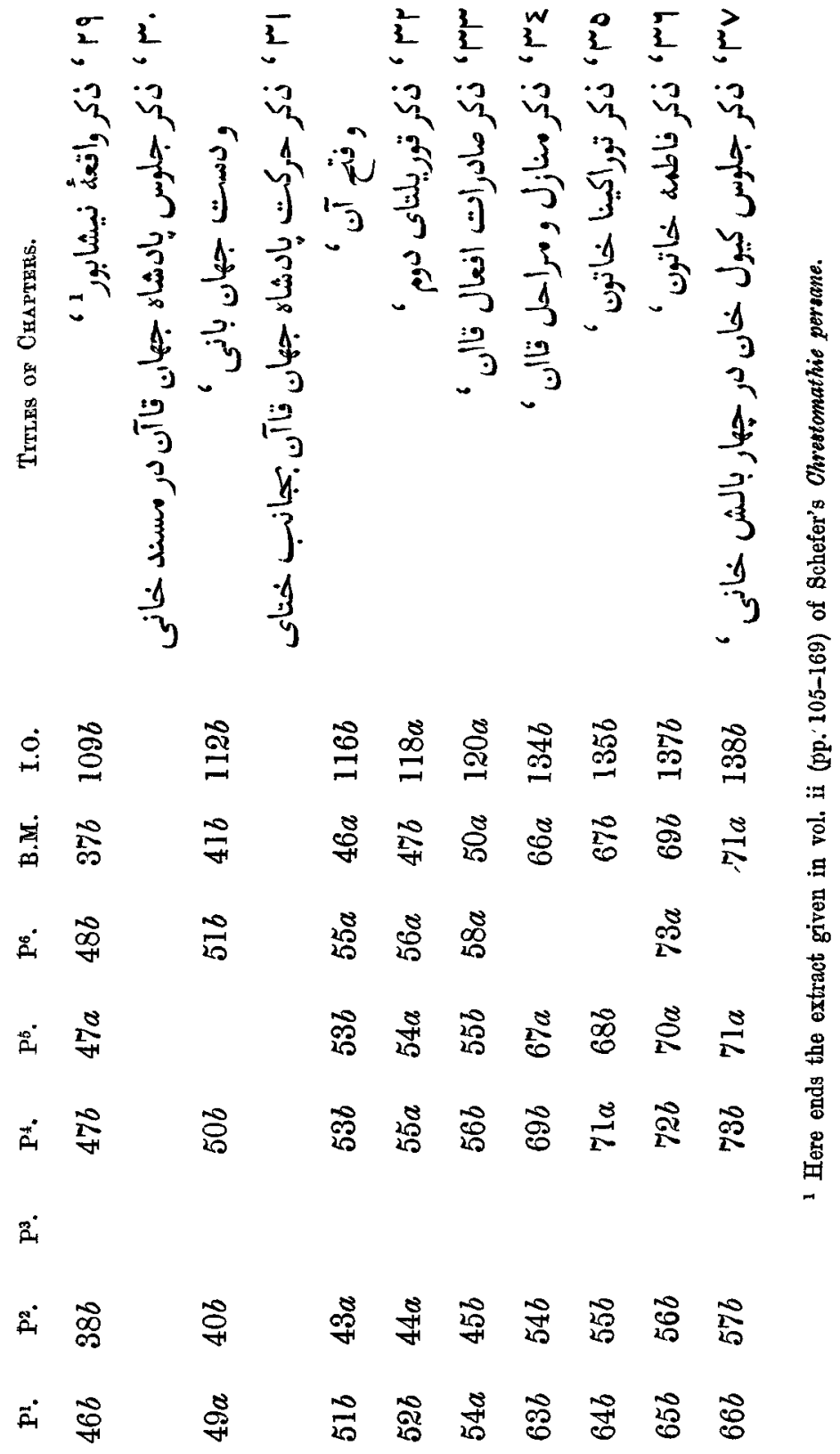



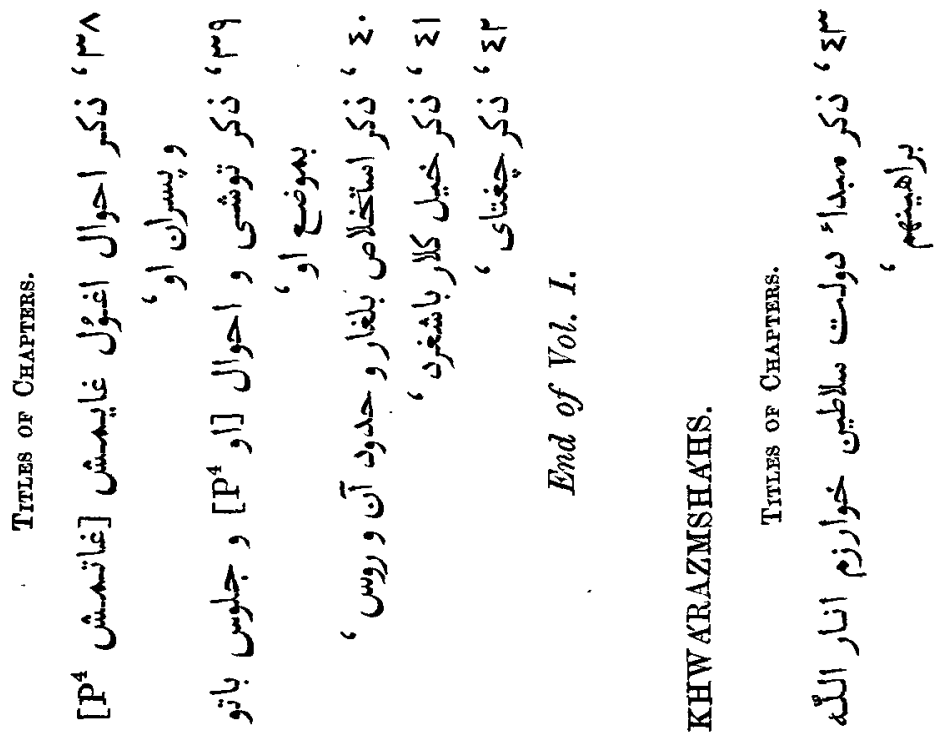

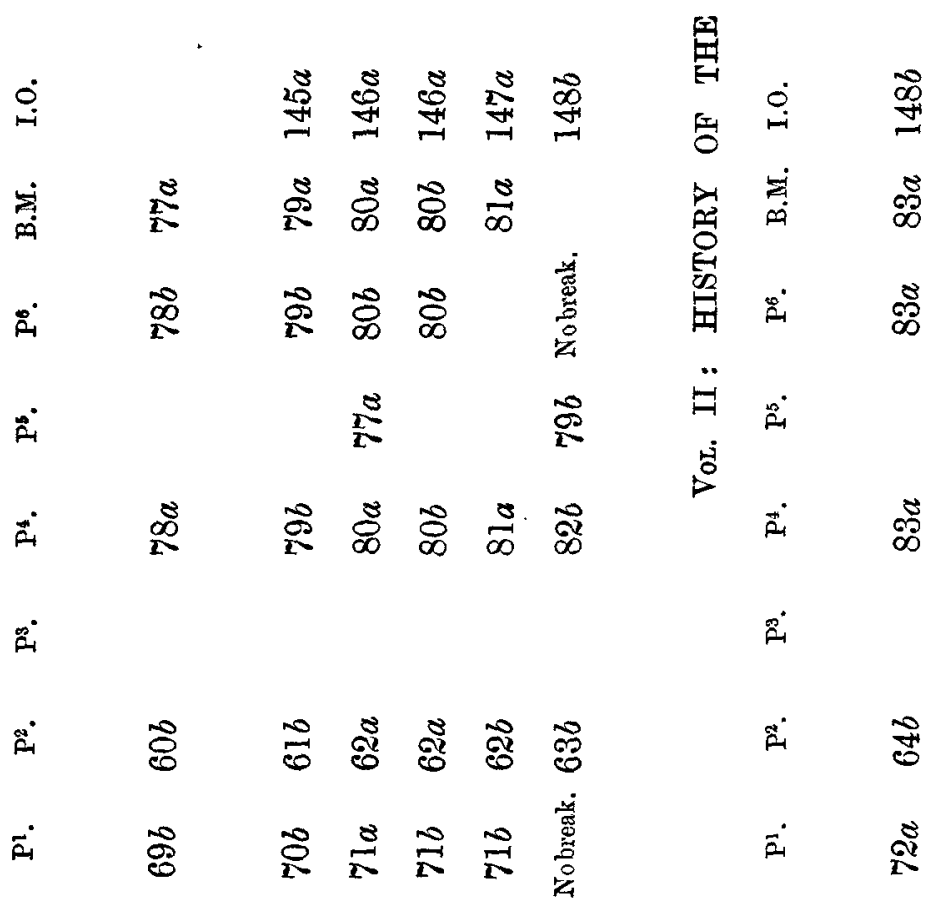


THE CONTENTS OF THE TA'RIKH-I-JAHAN-GUSHA. 39

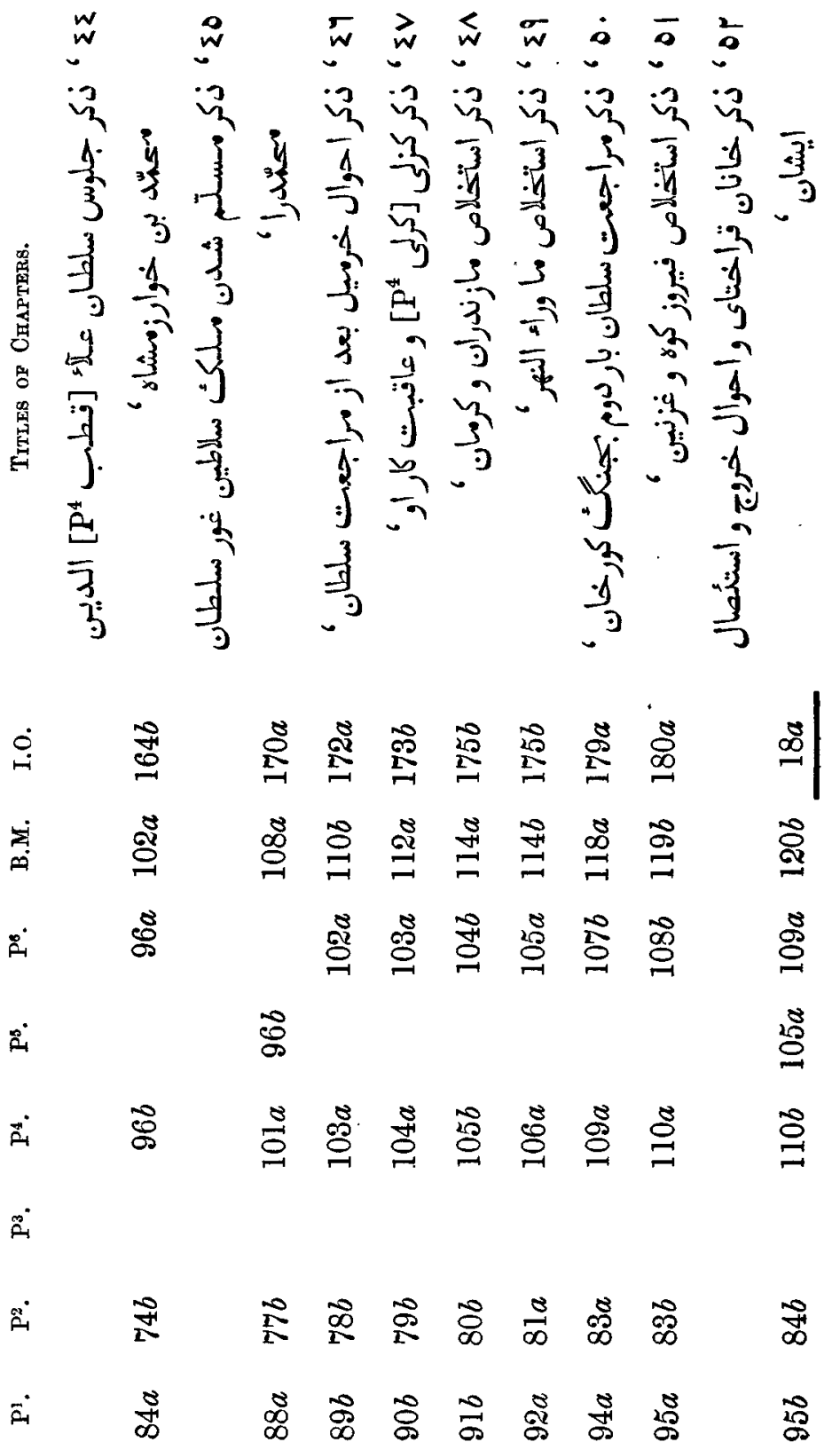


40 THE CONTENTS OF THE TA'RIKH-I-JAHAN-GUSHA.

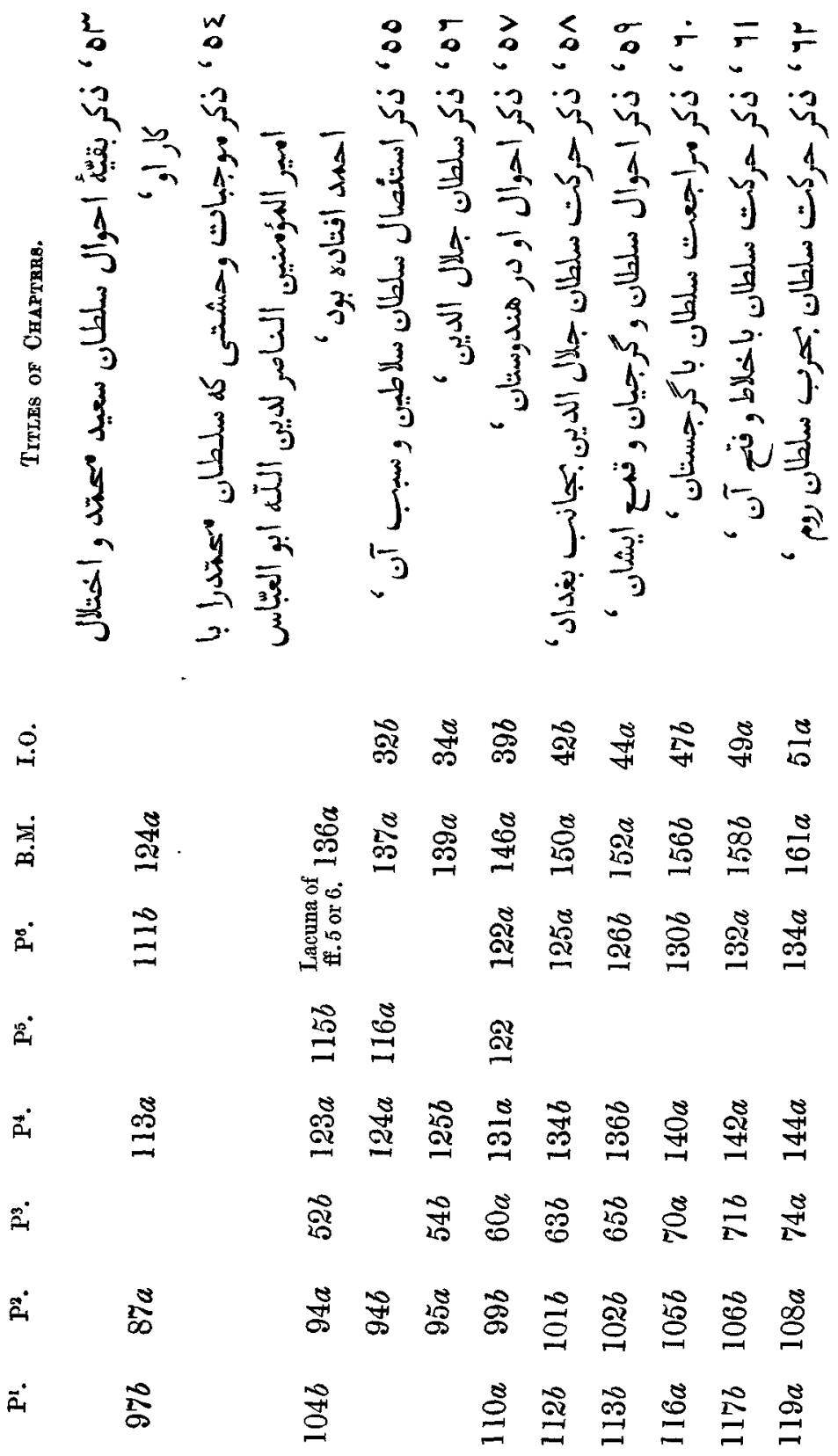




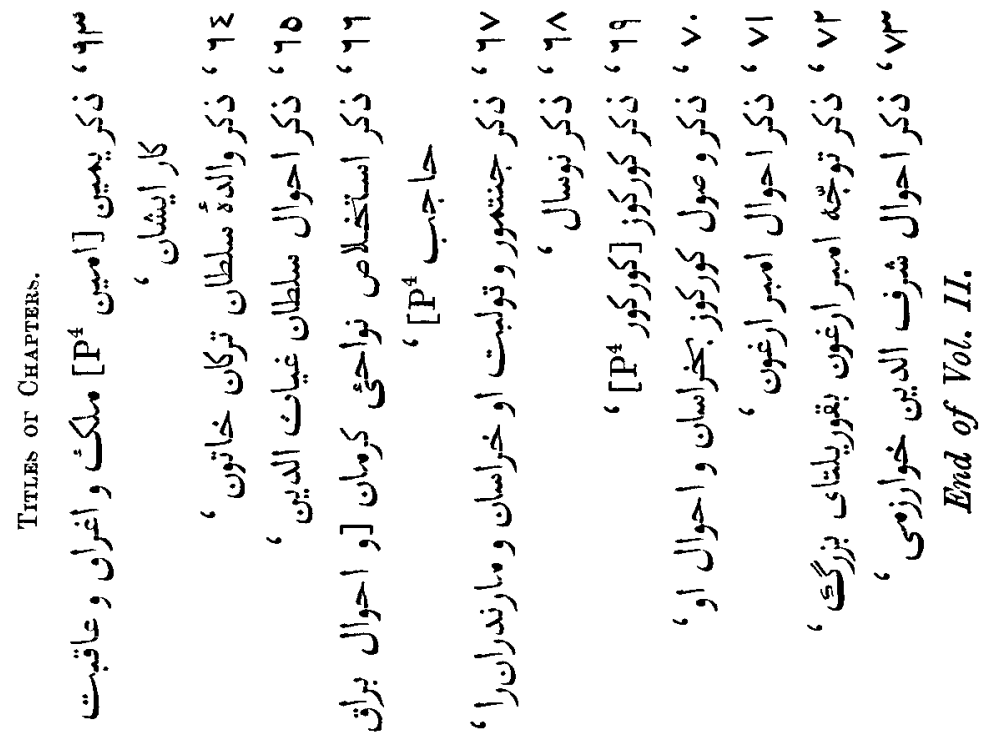

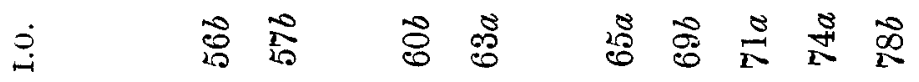

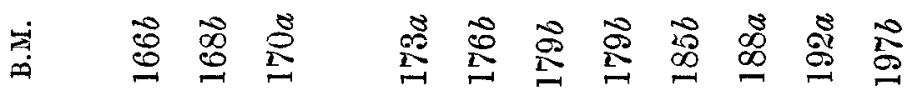

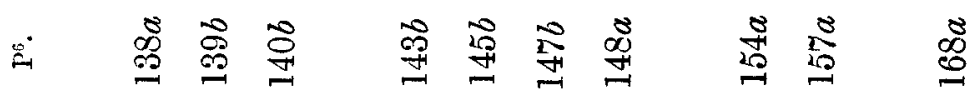

$\stackrel{\infty}{\therefore}$

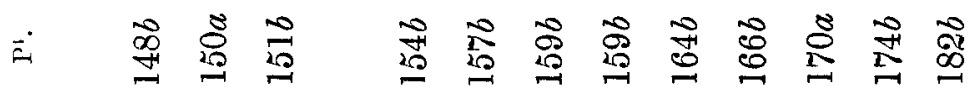

i. $\quad \infty \frac{\infty}{2} \stackrel{8}{2}$

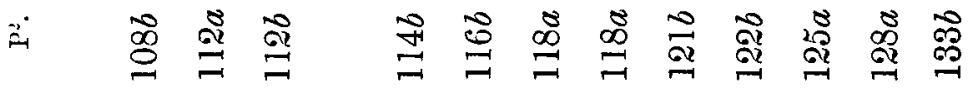

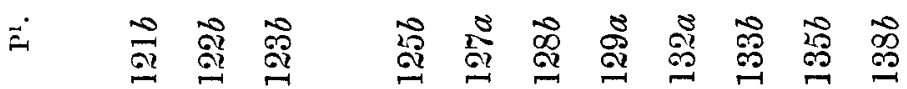




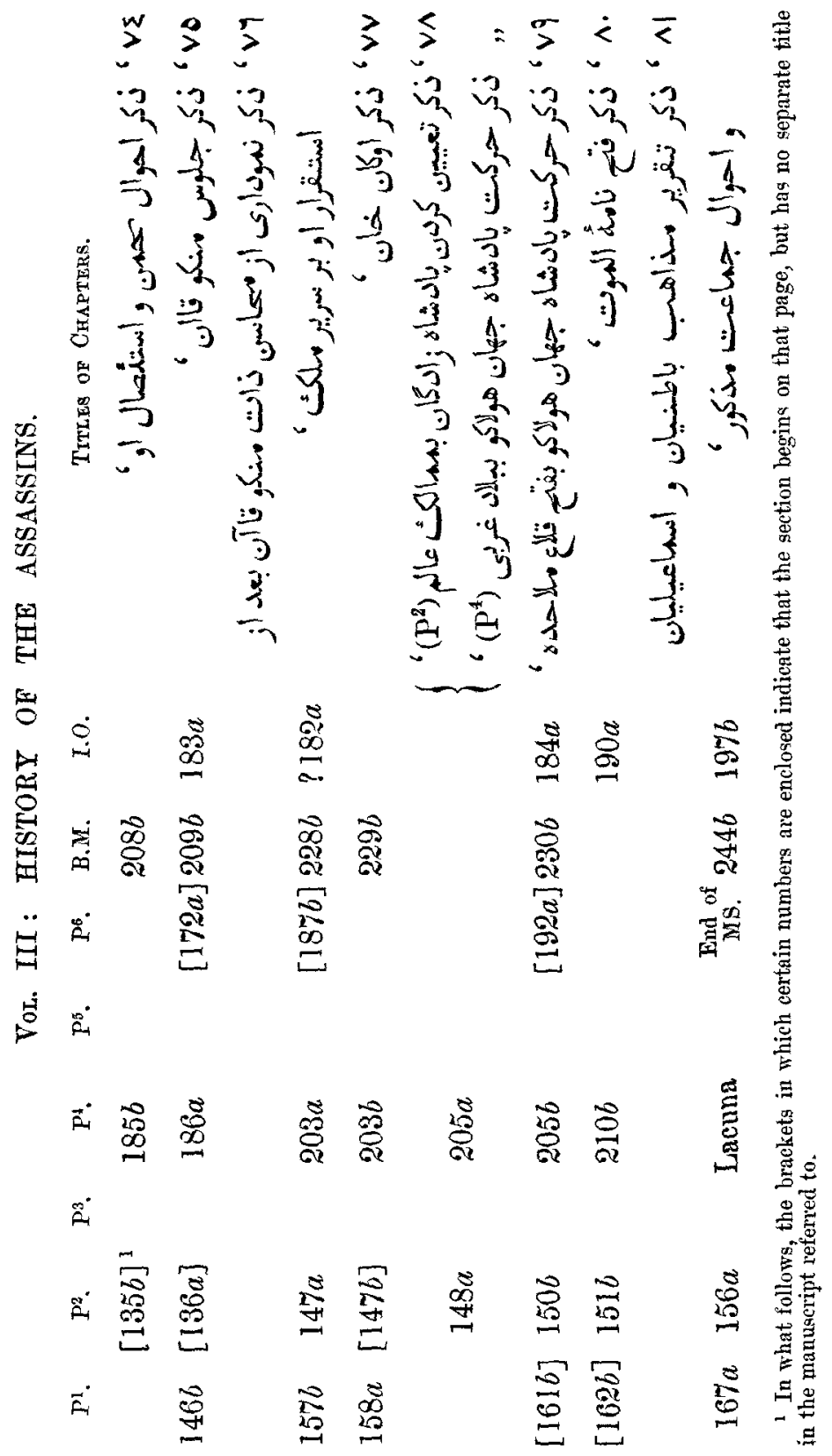


THE CONTENTS OF THE TA'RIKH-I-JAHAN-GUSHA. 43

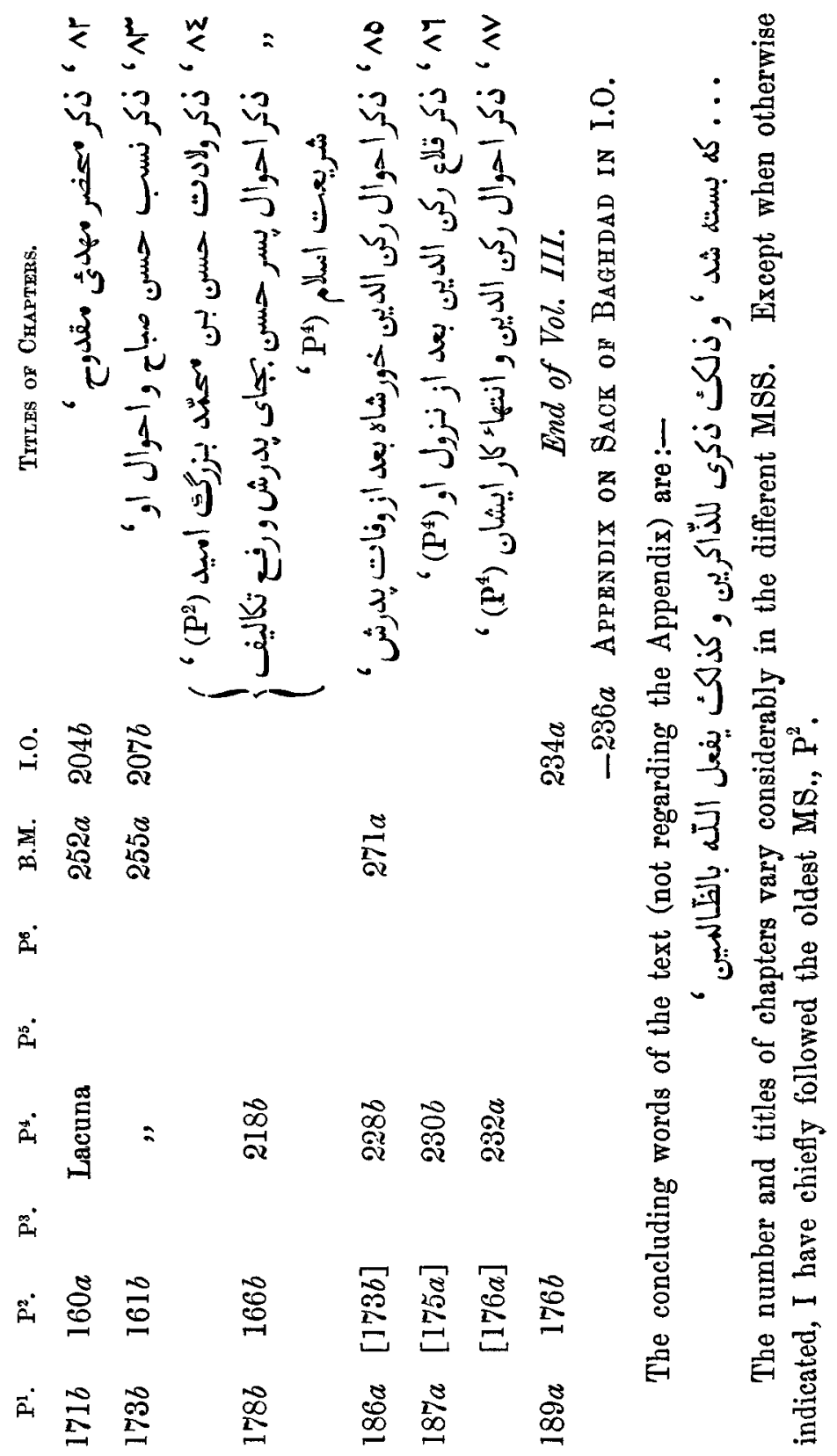

